\title{
Performance of lactating goats fed diets containing inactive dry yeast
}

\author{
Ludmila Couto Gomes ${ }^{1}$, Claudete Regina Alcalde ${ }^{1}$, Francisco de Assis Fonseca de Macedo', \\ Geraldo Tadeu dos Santos ${ }^{1}$, Altair Antônio Valloto ${ }^{2}$, Luciano Soares de Lima1, Bruna Susan \\ de Labio Molina ${ }^{1}$
}

\author{
${ }^{1}$ Universidade Estadual de Maringá - UEM. \\ ${ }^{2}$ Associação Paranaense dos Criadores de Bovinos da Raça Holandesa - APCBRH.
}

\begin{abstract}
Twenty-four Saanen goats (15 multiparous and 9 primiparous) from 21 days prepartum to 200 days in lactation were used to evaluate milk yield and composition. Animals were randomly distributed in a $3 \times 2$ factorial arrangement ( 3 diets $\times 2$ parity orders) and fed a 40:60 forage:concentrate diet composed of soybean meal, soybean meal + dry yeast or dry yeast as protein source, plus ground corn, mineral supplement and corn silage. The protein source did not influence the body weight of pre and postpartum goats. Prepartum, postpartum and postpeak dry matter intake (DMI) were not altered by diets. However, goats fed the diet containing dry yeast as protein source had lower DMI in late lactation. Milk yield and feed efficiency were not affected by diets. Milk components, acidity and somatic cell count were not influenced by diets during all lactation phases. However, fat and total solid contents postpartum were higher for primiparous goats and somatic cell count postpeak was lower for multiparous goats. Dry yeast can be used to replace soybean meal in diets for lactating Saanen goats.
\end{abstract}

Key Words: feed additive, lactation, parity, Saccharomyces cerevisiae

\section{Introduction}

The growing concerns with food and human health have brought about an increased interest for goat milk, because it is a nutritious, healthy and functional food. It has several elements needed for human nutrition such as sugars, proteins, fats, vitamins and minerals. In addition, goat milk can also be used in cosmetic products. These characteristics make the goat milk a product of great perspectives to the consumer market with growing tendencies.

Several factors can influence goat milk production and composition, such as diet, breed, lactation stage, climate, genetic factors, and the associated action of these factors in the environmental conditions of each country or region (Queiroga \& Costa, 2004). However, nutrition is the main factor that influences milk production and composition (Morand-Fehr, 2005), and fat is the most sensitive milk component to nutritional changes, whereas protein, lactose and minerals are little influenced by feed (Pulina et al., 2008).

Feed intake is the main factor in performance and production efficiency, and its study is necessary for the formulation of diets, to predict animal performance and to plan and to control the production system (Pina et al., 2006). Therefore, when alternative feeds are included in the diet, the ability of the feed to influence the animal performance should be evaluated.
Dry yeast, a by-product of ethanol industries, is composed of inactive cells of Saccharomyces cerevisiae, which is a rich source of protein, vitamins (mainly complex B) and minerals such as iron, zinc and selenium. It also has a carbohydrate fraction (20\% to $40 \%)$ consisting mostly of cell wall and a significant amount of nucleotides (Araújo $\&$ Silva, 2009). Therefore, it is an alternative feed used for livestock feeding.

This study was conducted to evaluate the milk yield and the composition of lactating Saanen goats fed diets containing inactive dry yeast in substitution to soybean meal.

\section{Material and Methods}

The study was performed at Fazenda Experimental de Iguatemi of Universidade Estadual de Maringá. Twentyfour Saanen goats (15 multiparous and 9 primiparous) from 21 days prepartum to 200 days in lactation were used. Goats were assigned at random to a $3 \times 2$ factorial arrangement ( 3 diets $\times 2$ parity orders) based on body weight and milk production for multiparous and body weight for primiparous cows.

Animals were allotted in single pens with free access to water. Body weight was recorded weekly until 60 days of lactation and every 15 days after 60 days of lactation. 
The treatments consisted of three different total mixed diets (Table 1), for all productive phases, containing forage:concentrate ratio of 40:60, composed of soybean meal, soybean meal plus inactive dry yeast or inactive dry yeast as protein source, and ground corn, mineral supplement, limestone and corn silage (Table 1). The

Table 1 - Ingredients and chemical composition of experimental diets

\begin{tabular}{lccc}
\hline & \multicolumn{3}{c}{ Diet } \\
\cline { 2 - 4 } Item $(\mathrm{g} / \mathrm{kg})$ & $\begin{array}{c}\text { Soybean } \\
\text { meal }\end{array}$ & $\begin{array}{c}\text { Soybean } \\
\text { meal plus } \\
\text { dry yeast }\end{array}$ & Dry yeast \\
\hline Corn silage & 400.0 & 400.0 & 400.0 \\
Ground corn & 425.3 & 397.3 & 357.9 \\
Soybean meal & 166.0 & 97.2 & \\
Dry yeast & & 97.2 & 234.1 \\
Limestone & 3.7 & 3.4 & 3.0 \\
Mineral supplement ${ }^{1}$ & 5.0 & 5.0 & 5.0
\end{tabular}

Prepartum

Dry matter $(\mathrm{g} / \mathrm{kg})$

Organic matter $(\mathrm{g} / \mathrm{kg} \mathrm{DM})$

Ash (g/kg DM)

Crude protein $(\mathrm{g} / \mathrm{kg} \mathrm{DM})$

656

Rumen degradable protein $(\mathrm{g} / \mathrm{kg} \mathrm{CP})^{2}$

958.9

41.1

166,1

578.2

26.7

Ether extract $(\mathrm{g} / \mathrm{kg} \mathrm{DM})$

315.9

168.4

766.2

$\begin{array}{cc}658.0 & 663.8 \\ 964.5 & 965.4 \\ 35.5 & 34.6 \\ 166,6 & 167,3 \\ 619.0 & 675.4 \\ 24.4 & 23.2 \\ 312.1 & 286.5 \\ 161.8 & 150.5 \\ 784.9 & 774.8\end{array}$

Acid detergent fiber $(\mathrm{g} / \mathrm{kg} \mathrm{DM})$
Total carbohydrate $(\mathrm{g} / \mathrm{kg} \mathrm{DM})$

Postpartum

Dry matter $(\mathrm{g} / \mathrm{kg})$

Organic matter $(\mathrm{g} / \mathrm{kg} \mathrm{DM})$

Ash (g/kg DM)

Crude protein $(\mathrm{g} / \mathrm{kg} \mathrm{DM})$

Rumen degradable protein $(\mathrm{g} / \mathrm{kg} \mathrm{CP})^{2}$

Ether extract (g/kg DM)

675.0

956.1

43.9

169.3

576.5

31.1

Neutral detergent fiber $(\mathrm{g} / \mathrm{kg} \mathrm{DM})$

Acid detergent fiber (g/kg DM)

290.4

150.4

755.7

679

958.3

672.3

966.3

$151.8 \quad 156.0$

$689.7 \quad 734.6$

$22.6 \quad 20.4$

$277.3 \quad 255.7$

$143.6 \quad 135.3$

$783.9 \quad 789.9$

Total carbohydrate $(\mathrm{g} / \mathrm{kg} \mathrm{DM})$
Postpeak

$\begin{array}{lccc}\text { Dry matter }(\mathrm{g} / \mathrm{kg}) & 647.6 & 646.8 & 639.4 \\ \text { Organic matter }(\mathrm{g} / \mathrm{kg} \mathrm{DM}) & 960.2 & 965.6 & 967.0 \\ \text { Ash }(\mathrm{g} / \mathrm{kg} \mathrm{DM}) & 39.8 & 34.4 & 33.0 \\ \text { Crude protein }(\mathrm{g} / \mathrm{kg} \mathrm{DM}) & 157.0 & 161.4 & 159.4 \\ \text { Rumen degradable protein }(\mathrm{g} / \mathrm{kg} \mathrm{CP})^{2} & 609.5 & 639.6 & 713.7 \\ \text { Ether extract }(\mathrm{g} / \mathrm{kg} \mathrm{DM}) & 41.0 & 30.7 & 27.6 \\ \text { Neutral detergent fiber }(\mathrm{g} / \mathrm{kg} \mathrm{DM}) & 338.1 & 330.5 & 306.5 \\ \text { Acid detergent fiber }(\mathrm{g} / \mathrm{kg} \mathrm{DM}) & 174.3 & 166.2 & 157.4 \\ \text { Total carbohydrate }(\mathrm{g} / \mathrm{kg} \mathrm{DM}) & 771.9 & 773.5 & 780.8\end{array}$

Late lactation

$\begin{array}{lccc}\text { Dry matter }(\mathrm{g} / \mathrm{kg}) & 639.2 & 638.8 & 641.0 \\ \text { Organic matter }(\mathrm{g} / \mathrm{kg} \mathrm{DM}) & 966.9 & 967.7 & 968.4 \\ \text { Ash }(\mathrm{g} / \mathrm{kg} \mathrm{DM}) & 33.1 & 32.3 & 31.6 \\ \text { Crude protein }(\mathrm{g} / \mathrm{kg} \mathrm{DM}) & 154.0 & 153.6 & 154.3 \\ \text { Rumen degradable protein }(\mathrm{g} / \mathrm{kg} \mathrm{CP})^{2} & 611.4 & 640.8 & 676.3 \\ \text { Ether extract }(\mathrm{g} / \mathrm{kg} \mathrm{DM}) & 29.7 & 30.3 & 25.7 \\ \text { Neutral detergent fiber }(\mathrm{g} / \mathrm{kg} \mathrm{DM}) & 304.5 & 287.5 & 269.0 \\ \text { Acid detergent fiber }(\mathrm{g} / \mathrm{kg} \mathrm{DM}) & 135.9 & 131.9 & 121.6 \\ \text { Total carbohydrate }(\mathrm{g} / \mathrm{kg} \mathrm{DM}) & 776.6 & 783.8 & 788.5\end{array}$

${ }^{1}$ Chemical composition (per kg of product) of commercial mixture ${ }^{\circledR}: \mathrm{Ca}-240 \mathrm{~g}$; P - 71 g; F - 710 mg (Max); Mg - 20 g; K - 28.2 g; S - 20 g; Fe - 2,500 mg; Cu - 400 mg; Mn - 1,350 mg; Zn - 1,700 mg; Co - 30 mg; I - 40 mg; Se - 15 mg; Cr - 10 mg; vit. A - 135,000 IU; vit. $\mathrm{D}_{3}$ - 68,000 IU; vit. E - $450 \mathrm{IU}$.

${ }^{2}$ Estimated from values of degradable protein recommended by the NRC (2007). inactive dry yeast (Saccharomyces cerevisiae) had 95\% of DM and $40.4 \%$ of CP.

Diets were formulated to meet the energy and protein requirements of goats averaging $60 \mathrm{~kg}$ of BW and $3.0 \mathrm{~kg}$ of milk/day from the NRC (2007). All goats were fed ad libitum (10\% orts) twice a day (09:30 and 16:00 h). Dry matter intake was calculated using the dry matter (DM) from total mixed ration and the DM refused in orts.

Samples of total mixed diets and orts were taken once every two weeks and polled per diet and animal. All samples were frozen at $-20{ }^{\circ} \mathrm{C}$ for subsequent drying at $55{ }^{\circ} \mathrm{C}$ and milling thought a $1 \mathrm{~mm}$ screen.

Dry matter was determined according to method no. 934.01 of AOAC (1998). Ash was determined by combustion in a muffle furnace according to method no. 942.05 (AOAC, 1998). Total nitrogen (TN) was determined using a Tecnal TE-036/1 (Tecnal, Piracicaba, São Paulo, Brazil) following method no. 988.05 of AOAC (1998) and crude protein $(\mathrm{CP})$ was estimated as $\mathrm{TN} \times 6.25$. Ether extraction in diets was conducted with Tecnal TE-044/1 according to the method no. 920.39 of AOAC (1998). The NDF content was determined as described by Van Soest (1991). Procedures for NDF determination were adapted for use in an Ankom ${ }^{200}$ fiber analyzer (Ankom Technology Corp., Fairport, NY). The ADF content was determined according to AOAC (1998), method no. 973.18. Total carbohydrates (TC) were estimated according to the equation described by Sniffen et al. (1992): TC $(\%)=100-(\% \mathrm{CP}+\% \mathrm{EE}+\%$ ash $)$.

The dietary rumen degradable protein (RDP) content was calculated according to the model of the NRC (2007). The values considered were $72.5 \%$; $42.2 \%$; and $64.4 \%$ for corn silage, ground corn and soybean meal, respectively. For inactive dry yeast, $80 \%$ of RDP from the crude protein was considered, because about $20 \%$ from the nitrogenous content are nucleic acids (Amorim \& Lopes, 2009).

Goats were milked manually twice daily $(07 \mathrm{~h} 30$ and $15 \mathrm{~h} 00$ ) and the milk yield of individual goats was measured on electronic balance at each milking. Lactation was divided in three productive phases: pospartum (until 60 days of lactation), postpeak (from 60 days to 130 days) and late lactation (from 130 days to 200 days of lactation).

Milk samples were collected every 15 days in the postpartum from each goat for two consecutive milking sessions and pooled on a yield basis. At postpeak, milk samples were collected once a month.

For chemical composition determination, milk samples were stored at $4{ }^{\circ} \mathrm{C}$ with a preservative (with 2-bromo2-nitropropane-1,3-diol) until analyzed for fat, protein, lactose, and total solids by infrared spectroscopy (Bentley model 2000; Bentley Instrument Inc., Chaska, MN). Milk 
somatic cell count (SCC) was obtained using an electronic counter (Somacount 500, Chaska, MN) as described by Voltolini et al. (2001). The equipment used is calibrated for cow milk analysis. At the same time milk acidity was measured according to the AOAC (1998, method $n^{\circ}$. 947.05), using the Dornic solution.

The data for milk yield and composition and feed intake collected in the experimental period, were analyzed using the following general model:

$$
\mathrm{Y}_{\mathrm{ijk}}=\mu+\mathrm{D}_{\mathrm{i}}+\mathrm{P}_{\mathrm{j}}+\mathrm{DP}_{\mathrm{ij}}+\mathrm{e}_{\mathrm{ijk}}
$$

in which: $\mathrm{Y}_{\mathrm{ijk}}=$ dependent variable; $\mu=$ overall mean; $\mathrm{D}_{\mathrm{i}}=$ effect of diet $i ; i=$ soybean meal, soybean meal + dry yeast, or dry yeast; $\mathrm{P}_{\mathrm{j}}=$ effect of Parity $j ; j=1$ for primiparous and $j=2$ for multiparous; $\mathrm{DP}_{\mathrm{ij}}=$ interaction between $\operatorname{diet} i$ and parity $j ; \mathrm{e}_{\mathrm{ijk}}=$ residual error.

The data obtained were analyzed using analyses of variance of the SAEG system, version 7.0, developed at Universidade Federal de Viçosa (2007), and the differences were evaluated by the Tukey test $(\mathrm{P}<0.05)$.

\section{Results and Discussion}

Body weight was similar between diets for primiparous and multiparous goats in all lactation phases (Table 2). However, multiparous goats showed greater body weight than primiparous. From prepartum to postpartum, primiparous goats lost $9.26 \mathrm{~kg}$ of BW, while the multiparous lost $12.74 \mathrm{~kg}$ of BW. Great part of the difference observed is related to the weight of the conceptus and fetal membranes; because newborn kids of primiparous goats weighted $4.88 \mathrm{~kg}$ and

Table 2 - Body weight of prepartum and in the lactation phases of Saanen goats fed experimental diets

\begin{tabular}{|c|c|c|c|c|}
\hline \multirow[b]{2}{*}{ Parity } & \multicolumn{3}{|c|}{ Diets } & \multirow[b]{2}{*}{ Mean } \\
\hline & $\begin{array}{c}\text { Soybean } \\
\text { meal }\end{array}$ & $\begin{array}{c}\text { Soybean meal } \\
+ \text { dry yeast }\end{array}$ & Dry yeast & \\
\hline & & Prepartum & & \\
\hline Primiparous & $56.08 \pm 4.85$ & $56.53 \pm 4.85$ & $57.13 \pm 4.85$ & $56.58 \pm 2.80 \mathrm{~B}$ \\
\hline Multiparous & $74.91 \pm 3.75$ & $75.59 \pm 3.75$ & $73.69 \pm 3.75$ & $74.71 \pm 2.17 \mathrm{~A}$ \\
\hline \multirow[t]{2}{*}{ Means } & $65.50 \pm 3.07$ & $66.03 \pm 3.07$ & $65.41 \pm 3.07$ & \\
\hline & & Postpartum & & \\
\hline Primiparous & $47.90 \pm 5.05$ & $44.79 \pm 5.05$ & $49.27 \pm 5.05$ & $47.32 \pm 2.92 \mathrm{~B}$ \\
\hline Multiparous & $61.26 \pm 3.91$ & $64.86 \pm 3.91$ & $59.80 \pm 3.91$ & $61.97 \pm 2.26 \mathrm{~A}$ \\
\hline \multirow[t]{2}{*}{ Means } & $54.58 \pm 3.19$ & $54.83 \pm 3.19$ & $54.53 \pm 3.19$ & \\
\hline & & Postpeak & & \\
\hline Primiparous & $51.09 \pm 5.42$ & $46.02 \pm 5.42$ & $51.53 \pm 5.42$ & $49.55 \pm 3.13 \mathrm{~B}$ \\
\hline Multiparous & $65.08 \pm 4.20$ & $67.38 \pm 4.20$ & $61.55 \pm 4.20$ & $64.67 \pm 2.42 \mathrm{~A}$ \\
\hline \multirow[t]{2}{*}{ Means } & $58.09 \pm 3.43$ & $56.70 \pm 3.43$ & $56.54 \pm 3.43$ & \\
\hline & & Late lactation & & \\
\hline Primiparous & $55.49 \pm 5.76$ & $54.92 \pm 5.76$ & $53.11 \pm 5.76$ & $54.51 \pm 3.32 \mathrm{~B}$ \\
\hline Multiparous & $69.05 \pm 4.46$ & $70.96 \pm 4.46$ & $64.78 \pm 4.46$ & $68.26 \pm 2.58 \mathrm{~A}$ \\
\hline Means & $62.27 \pm 3.64$ & $62.94 \pm 3.64$ & $58.95 \pm 3.64$ & \\
\hline
\end{tabular}

Means followed by different capital letters in the same column by the Tukey test $(\mathrm{P}<0.05)$. newborn kids of multiparous goats weighted $7.29 \mathrm{~kg}$, and $33.3 \%$ of the offspring from primiparous were twins, whereas in multiparous goats, they were $73.3 \%$. However, during the lactation, goats recovered the body weight. Primiparous goats showed higher average total body gain $(14.30 \%)$ than multiparous goats, which is related to the body development of younger goats.

Dry matter intake (DMI) was not influenced by diets at the different lactation phases, except for late lactation, when goats fed diet containing dry yeast had $28.40 \%$ greater DMI (Table 3). However, when the dry matter intake in percentage of body weight was compared, no differences were observed (Table 4).

Multiparous goats had greater prepartum, postpartum and postpeak dry matter intake sicompared with primiparous goats. However, late lactation dry matter intake was not affected by parity.

Table 3 - Dry matter intake and milk yield of Saanen goats fed experimental diets

\begin{tabular}{|c|c|c|c|c|}
\hline \multirow[b]{2}{*}{ Parity } & \multicolumn{3}{|c|}{ Diets } & \multirow[b]{2}{*}{ Mean } \\
\hline & Soybean meal & $\begin{array}{c}\text { Soybean meal } \\
+ \text { dry yeast }\end{array}$ & Dry yeast & \\
\hline \multicolumn{5}{|c|}{ Dry matter intake $(\mathrm{kg} /$ day $)$} \\
\hline \multicolumn{5}{|c|}{ Prepartum } \\
\hline Primiparous & $56.08 \pm 4.85$ & $56.53 \pm 4.85$ & $57.13 \pm 4.85$ & $56.58 \pm 2.80 \mathrm{~B}$ \\
\hline Multiparous & $74.91 \pm 3.75$ & $75.59 \pm 3.75$ & $73.69 \pm 3.75$ & $74.71 \pm 2.17 \mathrm{~A}$ \\
\hline Means & $65.50 \pm 3.07$ & $66.03 \pm 3.07$ & $65.41 \pm 3.07$ & \\
\hline \multicolumn{5}{|c|}{ Postpartum } \\
\hline Primiparous & $47.90 \pm 5.05$ & $44.79 \pm 5.05$ & $49.27 \pm 5.05$ & $47.32 \pm 2.92 \mathrm{~B}$ \\
\hline Multiparous & $61.26 \pm 3.91$ & $64.86 \pm 3.91$ & $59.80 \pm 3.91$ & $61.97 \pm 2.26 \mathrm{~A}$ \\
\hline Means & $54.58 \pm 3.19$ & $54.83 \pm 3.19$ & $54.53 \pm 3.19$ & \\
\hline \multicolumn{5}{|c|}{ Postpeak } \\
\hline Primiparous & $51.09 \pm 5.42$ & $46.02 \pm 5.42$ & $51.53 \pm 5.42$ & $49.55 \pm 3.13 \mathrm{~B}$ \\
\hline Multiparous & $65.08 \pm 4.20$ & $67.38 \pm 4.20$ & $61.55 \pm 4.20$ & $64.67 \pm 2.42 \mathrm{~A}$ \\
\hline Means & $58.09 \pm 3.43$ & $56.70 \pm 3.43$ & $56.54 \pm 3.43$ & \\
\hline \multicolumn{5}{|c|}{ Late lactation } \\
\hline Primiparous & $55.49 \pm 5.76$ & $54.92 \pm 5.76$ & $53.11 \pm 5.76$ & $54.51 \pm 3.32 \mathrm{~B}$ \\
\hline Multiparous & $69.05 \pm 4.46$ & $70.96 \pm 4.46$ & $64.78 \pm 4.46$ & $68.26 \pm 2.58 \mathrm{~A}$ \\
\hline Means & $62.27 \pm 3.64$ & $62.94 \pm 3.64$ & $58.95 \pm 3.64$ & \\
\hline \multicolumn{5}{|c|}{ Milk yield (kg/day) } \\
\hline \multicolumn{5}{|c|}{ Postpartum } \\
\hline Primiparous & $2.98 \pm 0.36$ & $2.18 \pm 0.36$ & $2.29 \pm 0.36$ & $2.48 \pm 0.21 \mathrm{~B}$ \\
\hline Multiparous & $3.44 \pm 0.28$ & $3.69 \pm 0.28$ & $3.82 \pm 0.28$ & $3.65 \pm 0.16 \mathrm{~A}$ \\
\hline Means & $3.21 \pm 0.23$ & $2.94 \pm 0.23$ & $3.06 \pm 0.23$ & \\
\hline \multicolumn{5}{|c|}{ Postpeak } \\
\hline Primiparous & $3.46 \pm 0.58$ & $2.20 \pm 0.58$ & $2.17 \pm 0.58$ & $2.61 \pm 0.34 \mathrm{~B}$ \\
\hline Multiparous & $4.03 \pm 0.45$ & $3.39 \pm 0.45$ & $3.59 \pm 0.45$ & $3.67 \pm 0.26 \mathrm{~A}$ \\
\hline Means & $3.75 \pm 0.37$ & $2.79 \pm 0.37$ & $2.88 \pm 0.37$ & \\
\hline \multicolumn{5}{|c|}{ Late lactation } \\
\hline Primiparous & $3.30 \pm 0.37$ & $2.19 \pm 0.37$ & $2.00 \pm 0.37$ & $2.50 \pm 0.22 \mathrm{~B}$ \\
\hline Multiparous & $3.37 \pm 0.29$ & $3.19 \pm 0.29$ & $3.41 \pm 0.29$ & $3.32 \pm 0.17 \mathrm{~A}$ \\
\hline Means & $3.34 \pm 0.24$ & $2.69 \pm 0.24$ & $2.71 \pm 0.24$ & \\
\hline
\end{tabular}

Means followed by different capital letters in the same column or lowercase letters in the same row differ by the Tukey test $(\mathrm{P}<0.05)$. 
Greater differences in dry matter intake due to parity were observed in postpartum, when the dry matter intake of multiparous goats was $53.3 \%$ higher than primiparous, and in percentage of body weight, intake was $18.5 \%$ higher.

The reasons for the greater postpartum dry matter intake $(\mathrm{kg})$ in multiparous goats compared with primiparous are probably related to greater body weight of multiparous $(61.97 \pm 2.26$ vs. $47.32 \pm 2.92)$ that tends to increase the requirement of nutrients for maintenance. Differences in the dry matter intake of dairy goats due to body weight were also reported by Lima (2010), which agree with the current experiment.

Dry matter intake $(\% \mathrm{BW})$ was not influenced by experimental diets or parity in phases, with average $2.26 \%$, $3.63 \%$ and $3.26 \%$ for prepartum, postpeak and late lactation. These values were higher than the observed by Zambom (2006), who reported values between 1.05 and $1.67 \mathrm{~kg} / \mathrm{day}$ (1.18 and $2.17 \% \mathrm{BW}$ ) of dry matter intake from prepartum and $2.21 \mathrm{~kg} /$ day $(2.93 \% \mathrm{BW})$ of dry matter intake from 60 days in milk for Saanen goats fed a corn silage with 40:60 forage:concentrate ratio.

However, Mendes et al. (2010) partially replaced soybean meal by urea or starea in diets with $40 \%$ corn silage of lactating (110 days) Saanen and Pardo Alpina goats (primiparous and multiparous) and reported $2.24 \mathrm{~kg}$ $\mathrm{DMI} /$ day $(3.40 \% \mathrm{BW})$; the values were similar to the observed in this study. These variations may be related to body weight, productive stage and diet composition.

Table 4 - Dry matter intake (\% of body weight) prepartum and in the lactation phases of Saanen goats fed experimental diets

\begin{tabular}{|c|c|c|c|c|}
\hline \multirow[b]{2}{*}{ Parity } & \multicolumn{3}{|c|}{ Diets } & \multirow[b]{2}{*}{ Mean } \\
\hline & $\begin{array}{c}\text { Soybean } \\
\text { meal }\end{array}$ & $\begin{array}{c}\text { Soybean meal } \\
+ \text { dry yeast }\end{array}$ & Dry yeast & \\
\hline \multicolumn{5}{|c|}{ Prepartum } \\
\hline Primiparous & $2.29 \pm 0.18$ & $2.37 \pm 0.18$ & $2.39 \pm 0.18$ & $2.17 \pm 0.13$ \\
\hline Multiparous & $2.26 \pm 0.23$ & $2.01 \pm 0.23$ & $2.24 \pm 0.23$ & $2.35 \pm 0.10$ \\
\hline Means & $2.28 \pm 0.15$ & $2.19 \pm 0.15$ & $2.31 \pm 0.15$ & $2.26 \pm 0.08$ \\
\hline \multicolumn{5}{|c|}{ Postpartum } \\
\hline Primiparous & $3.77 \pm 0.35$ & $2.80 \pm 0.35$ & $2.97 \pm 0.35$ & $3.18 \pm 0.20 \mathrm{~B}$ \\
\hline Multiparous & $3.89 \pm 0.27$ & $3.60 \pm 0.27$ & $3.81 \pm 0.27$ & $3.77 \pm 0.16 \mathrm{~A}$ \\
\hline Means & $3.83 \pm 0.22$ & $3.20 \pm 0.22$ & $3.39 \pm 0.22$ & \\
\hline \multicolumn{5}{|c|}{ Postpeak } \\
\hline Primiparous & $4.05 \pm 0.40$ & $3.20 \pm 0.40$ & $3.24 \pm 0.40$ & $3.60 \pm 0.23$ \\
\hline Multiparous & $3.64 \pm 0.31$ & $3.71 \pm 0.31$ & $3.64 \pm 0.31$ & $3.66 \pm 0.18$ \\
\hline Means & $3.99 \pm 0.25$ & $3.46 \pm 0.25$ & $3.44 \pm 0.25$ & $3.63 \pm 0.15$ \\
\hline \multicolumn{5}{|c|}{ Late lactation } \\
\hline Primiparous & $4.03 \pm 0.42$ & $3.71 \pm 0.42$ & $2.59 \pm 0.42$ & $3.44 \pm 0.24$ \\
\hline Multiparous & $3.27 \pm 0.32$ & $3.08 \pm 0.32$ & $2.88 \pm 0.32$ & $3.08 \pm 0.19$ \\
\hline Means & $3.65 \pm 0.26$ & $3.39 \pm 0.26$ & $2.74 \pm 0.26$ & $3.26 \pm 0.15$ \\
\hline
\end{tabular}

Means followed by different capital letters in the same column differ by the Tukey test $(\mathrm{P}<0.05)$.
Milk yield was not affected by diets and was similar between the lactation phases (Table 3 ).

Production peak was on days 88,82 and 46 for primiparous and on days 54, 42 and 49 for multiparous goats for soybean meal, soybean meal plus inactive dry yeast and inactive dry yeast, respectively. Primiparous goats had peak production later than the multiparous goats, reflecting different productive characteristics between the parity classifications.

Feed efficiency was not affected by diets and parity (Table 5), with an average of 1.54 . In a study with goats, Zambom et al. (2005) reported 1.58 of feed efficiency for Saanen goats in early lactation fed diets with different forage:concentrate ratios. Rodrigues et al. (2007) reported values from 1.18 to 1.34 of feed efficiency for Alpine goats (60 days of lactation) fed diets with the same amount of energy but different levels of protein. However, Lima (2010) reported values from 0.89 to 1.45 of milk yield efficiency for Saanen goats from 60 days of lactation and Mendes et al. (2010) observed 1.15 of feed efficiency for goats with 110 days in milk. Thus, milk yield efficiency may be related to the productive potential and the intake capacity of each animal.

Milk protein and lactose contents and acidity of milk were not affected by diets or parity (Tables 6 and 7) in all production periods. However, postpartum milk fat and total solids were higher for primiparous goats (Table 6) and somatic cell count was lower for multiparous goats in the postpeak phase (Table 6).

The lower fat and total solid contents for multiparous goats are caused by the dilution effect as a consequence of the higher milk yield (Table 3), which directly affects the milk fat content (Kala \& Prakash, 1990).

Table 5 - Feed efficiency ( $\mathrm{kg}$ of milk yield/ $\mathrm{kg}$ of intake dry matter) of Saanen goats fed experimental diets

\begin{tabular}{lcccc}
\hline & \multicolumn{3}{c}{ Diets } & \multirow{2}{*}{ Mean } \\
\cline { 2 - 4 } Parity & Soybean meal & $\begin{array}{c}\text { Soybean meal } \\
\text { +dry yeast }\end{array}$ & Dry yeast & \\
\hline & \multicolumn{3}{c}{ Prepartum } \\
Primiparous & $1.68 \pm 0.15$ & $1.76 \pm 0.15$ & $1.59 \pm 0.15$ & $1.68 \pm 0.09$ \\
Multiparous & $1.49 \pm 0.12$ & $1.59 \pm 0.12$ & $1.70 \pm 0.12$ & $1.59 \pm 0.07$ \\
Means & $1.58 \pm 0.10$ & $1.68 \pm 0.10$ & $1.64 \pm 0.10$ & $1.63 \pm 0.06$ \\
& & Postpartum & & \\
Primiparous & $1.58 \pm 0.17$ & $1.51 \pm 0.17$ & $1.28 \pm 0.17$ & $1.46 \pm 0.10$ \\
Multiparous & $1.73 \pm 0.13$ & $1.35 \pm 0.13$ & $1.61 \pm 0.13$ & $1.56 \pm 0.08$ \\
Means & $1.66 \pm 0.11$ & $1.43 \pm 0.11$ & $1.44 \pm 0.11$ & $1.51 \pm 0.06$ \\
& & Late lactation & & \\
Primiparous & $1.59 \pm 0.20$ & $1.09 \pm 0.20$ & $1.38 \pm 0.20$ & $1.35 \pm 0.11$ \\
Multiparous & $1.55 \pm 0.15$ & $1.49 \pm 0.15$ & $1.86 \pm 0.15$ & $1.63 \pm 0.09$ \\
Means & $1.57 \pm 0.12$ & $1.29 \pm 0.12$ & $1.61 \pm 0.12$ & $1.49 \pm 0.07$ \\
\hline
\end{tabular}


Table 6 - Milk components of postpartum and postpeak Saanen goats fed experimental diets

\begin{tabular}{|c|c|c|c|c|}
\hline \multirow[b]{2}{*}{ Parity } & \multicolumn{3}{|c|}{ Diets } & \multirow[b]{2}{*}{ Mean } \\
\hline & Soybean meal & $\begin{array}{c}\text { Soybean meal } \\
+ \text { dry yeast }\end{array}$ & Dry yeast & \\
\hline \multicolumn{5}{|c|}{ Postpartum } \\
\hline \multicolumn{5}{|c|}{ Fat $(\mathrm{g} / \mathrm{kg})$} \\
\hline Primiparous & $38.6 \pm 2.3$ & $39.2 \pm 2.3$ & $36.7 \pm 2.3$ & $38.2 \pm 1.32 \mathrm{~A}$ \\
\hline Multiparous & $34.2 \pm 1.8$ & $35.7 \pm 1.8$ & $29.9 \pm 1.8$ & $33.3 \pm 1.02 \mathrm{~B}$ \\
\hline Mean & $36.4 \pm 1.4$ & $37.4 \pm 1.4$ & $33.3 \pm 1.4$ & \\
\hline \multicolumn{5}{|c|}{ Protein $(\mathrm{g} / \mathrm{kg})$} \\
\hline Primiparous & $29.2 \pm 1.5$ & $24.9 \pm 1.5$ & $29.9 \pm 1.5$ & $28.0 \pm 0.8$ \\
\hline Multiparous & $28.4 \pm 1.1$ & $27.5 \pm 1.1$ & $27.8 \pm 1.1$ & $27.9 \pm 0.7$ \\
\hline Mean & $28.8 \pm 0.9$ & $26.2 \pm 0.9$ & $28.8 \pm 0.9$ & $27.9 \pm 0.5$ \\
\hline \multicolumn{5}{|c|}{ Lactose $(\mathrm{g} / \mathrm{kg})$} \\
\hline Primiparous & $42.8 \pm 0.8$ & $43.1 \pm 0.8$ & $43.4 \pm 0.8$ & $43.1 \pm 0.4$ \\
\hline Multiparous & $42.8 \pm 0.6$ & $43.0 \pm 0.6$ & $42.1 \pm 0.6$ & $42.6 \pm 0.3$ \\
\hline Mean & $42.8 \pm 0.5$ & $43.0 \pm 0.5$ & $42.8 \pm 0.5$ & $42.9 \pm 0.3$ \\
\hline \multicolumn{5}{|c|}{ Total solids $(\mathrm{g} / \mathrm{kg})$} \\
\hline Primiparous & $119.9 \pm 4.6$ & $116.9 \pm 4.6$ & $119.6 \pm 4.6$ & $118.8 \pm 2.7 \mathrm{~A}$ \\
\hline Multiparous & $110.0 \pm 3.6$ & $115.6 \pm 3.6$ & $109.1 \pm 3.6$ & $111.6 \pm 2.1 \mathrm{~B}$ \\
\hline Mean & $114.9 \pm 2.9$ & $116.3 \pm 2.9$ & $114.3 \pm 2.9$ & \\
\hline \multicolumn{5}{|c|}{ Acidity $\left({ }^{\circ} \mathrm{D}\right)$} \\
\hline Primiparous & $16.94 \pm 0.86$ & $15.60 \pm 0.86$ & $16.32 \pm 0.86$ & $16.29 \pm 0.50$ \\
\hline Multiparous & $16.24 \pm 0.68$ & $17.24 \pm 0.68$ & $16.14 \pm 0.68$ & $16.54 \pm 0.39$ \\
\hline Mean & $16.59 \pm 0.55$ & $16.42 \pm 0.55$ & $16.23 \pm 0.55$ & $16.41 \pm 0.31$ \\
\hline \multicolumn{5}{|c|}{ Somatic cell count $\left(\log _{10}\right)$} \\
\hline Primiparous & $2.80 \pm 0.23$ & $3.28 \pm 0.23$ & $2.83 \pm 0.23$ & $2.97 \pm 0.13$ \\
\hline Multiparous & $2.61 \pm 0.18$ & $2.88 \pm 0.18$ & $2.59 \pm 0.18$ & $2.69 \pm 0.10$ \\
\hline Mean & $2.70 \pm 0.14$ & $3.08 \pm 0.14$ & $2.71 \pm 0.14$ & $2.83 \pm 0.08$ \\
\hline \multicolumn{5}{|c|}{ Postpeak } \\
\hline \multicolumn{5}{|c|}{ Fat $(\mathrm{g} / \mathrm{kg})$} \\
\hline Primiparous & $34.6 \pm 2.3$ & $28.3 \pm 2.3$ & $31.3 \pm 2.3$ & $31.4 \pm 1.3$ \\
\hline Multiparous & $32.1 \pm 1.7$ & $33.7 \pm 1.7$ & $28.4 \pm 1.7$ & $31.4 \pm 1.0$ \\
\hline Mean & $33.3 \pm 1.4$ & $31.0 \pm 1.4$ & $29.9 \pm 1.4$ & $31.4 \pm 0.8$ \\
\hline \multicolumn{5}{|c|}{ Protein $(\mathrm{g} / \mathrm{kg})$} \\
\hline Primiparous & $29.1 \pm 1.3$ & $26.5 \pm 1.3$ & $29.0 \pm 1.3$ & $28.2 \pm 0.8$ \\
\hline Multiparous & $29.0 \pm 1.0$ & $27.5 \pm 1.0$ & $28.4 \pm 1.0$ & $28.3 \pm 0.6$ \\
\hline Mean & $29.1 \pm 0.8$ & $27.0 \pm 0.8$ & $28.7 \pm 0.8$ & $28.3 \pm 0.5$ \\
\hline \multicolumn{5}{|c|}{ Lactose $(\mathrm{g} / \mathrm{kg})$} \\
\hline Primiparous & $41.9 \pm 0.9$ & $41.5 \pm 0.9$ & $41.8 \pm 0.9$ & $41.7 \pm 0.5$ \\
\hline Multiparous & $41.9 \pm 0.8$ & $42.1 \pm 0.8$ & $41.1 \pm 0.8$ & $41.7 \pm 0.4$ \\
\hline Mean & $41.9 \pm 0.6$ & $41.8 \pm 0.6$ & $41.4 \pm 0.6$ & $41.7 \pm 0.3$ \\
\hline \multicolumn{5}{|c|}{ Total solids ( $\mathrm{g} / \mathrm{kg}$ ) } \\
\hline Primiparous & $112.5 \pm 4.1$ & $103.5 \pm 4.1$ & $109.8 \pm 4.1$ & $108.6 \pm 2.3$ \\
\hline Multiparous & $110.8 \pm 3.1$ & $112.2 \pm 3.1$ & $105.4 \pm 3.1$ & $109.5 \pm 1.8$ \\
\hline Mean & $111.7 \pm 2.6$ & $107.8 \pm 2.6$ & $107.6 \pm 2.6$ & $109.1 \pm 1.5$ \\
\hline \multicolumn{5}{|c|}{ Acidity $\left({ }^{\circ} \mathrm{D}\right)$} \\
\hline Primiparous & $16.32 \pm 0.92$ & $15.86 \pm 0.92$ & $15.69 \pm 0.92$ & $15.95 \pm 0.53$ \\
\hline Multiparous & $16.64 \pm 0.71$ & $16.16 \pm 0.71$ & $15.54 \pm 0.71$ & $16.11 \pm 0.41$ \\
\hline Mean & $16.48 \pm 0.58$ & $16.01 \pm 0.58$ & $15.61 \pm 0.58$ & $16.03 \pm 0.34$ \\
\hline \multicolumn{5}{|c|}{ Somatic cell count $\left(\log _{10}\right)$} \\
\hline Primiparous & $2.97 \pm 0.19$ & $3.33 \pm 0.19$ & $3.13 \pm 0.19$ & $3.14 \pm 0.11 \mathrm{~A}$ \\
\hline Multiparous & $2.88 \pm 0.15$ & $3.02 \pm 0.15$ & $2.60 \pm 0.15$ & $2.84 \pm 0.09 \mathrm{~B}$ \\
\hline Mean & $2.93 \pm 0.12$ & $3.17 \pm 0.12$ & $2.87 \pm 0.12$ & \\
\hline
\end{tabular}

Means followed by different capital letters in the same column differ by the Tukey test $(\mathrm{P}<0.05)$.
The milk protein contents obtained agree with the range (2.64 to $2.96 \%)$ reported in the literature (Rodrigues et al., 2006; Queiroga et al., 2007; Vilanova et al., 2008). According to Santos \& Fonseca (2007), the milk protein content is not much influenced by the diet, whereas $55 \%$ of the variability in the composition of milk has genetic origin.

For lactose, small variations were observed between lactation phases $(4.29 \%$ in postpartum; $4.16 \%$ in the postpeak and $4.0 \%$ in late lactation). Lactose is synthesized and secreted at the same rate as the milk, which makes it the most stable milk nutrient (Pulina et al., 2008) and parity did not affect the lactose content (Tables 5, 6 and 7). The values obtained are close to the values $(4.10 \%$ and 4.04\%) reported by Queiroga et al. (2007) and Lima (2010), respectively.

Milk acidity values were in the limit range (from 11 to $18{ }^{\circ} \mathrm{D}$ or 0.11 to $0.18 \%$ lactic acid) according to Brasil (2000), so the changes observed may be related to differences in carboxylic acid contents and the microbiological profile of milk.

The average value for somatic cell count exceeded the value of $1000 \times 10^{-3} / \mathrm{mL}$ for goats proposed by

Table 7 - Milk components of late lactation of Saanen goats fed experimental diets

\begin{tabular}{|c|c|c|c|c|}
\hline \multirow[b]{2}{*}{ Parity } & \multicolumn{3}{|c|}{ Diets } & \multirow[b]{2}{*}{ Mean } \\
\hline & $\begin{array}{c}\text { Soybean } \\
\text { meal }\end{array}$ & $\begin{array}{c}\text { Soybean meal } \\
+ \text { dry yeast }\end{array}$ & Dry yeast & \\
\hline \multicolumn{5}{|c|}{ Fat $(\mathrm{g} / \mathrm{kg})$} \\
\hline Primiparous & $29.5 \pm 2.0$ & $2.91 \pm 0.20$ & $2.85 \pm 0.20$ & $2.90 \pm 0.11$ \\
\hline Multiparous & $29.4 \pm 1.6$ & $3.03 \pm 0.16$ & $2.70 \pm 0.16$ & $2.89 \pm 0.09$ \\
\hline Mean & $29.4 \pm 1.3$ & $2.97 \pm 0.13$ & $2.77 \pm 0.13$ & $2.90 \pm 0.07$ \\
\hline \multicolumn{5}{|c|}{ Protein $(\mathrm{g} / \mathrm{kg})$} \\
\hline Primiparous & $29.7 \pm 1.1$ & $29.0 \pm 1.1$ & $28.4 \pm 1.1$ & $29.0 \pm 0.7$ \\
\hline Multiparous & $29.5 \pm 0.9$ & $27.5 \pm 0.9$ & $28.6 \pm 0.9$ & $28.6 \pm 0.5$ \\
\hline Mean & $29.6 \pm 0.7$ & $28.2 \pm 0.7$ & $28.5 \pm 0.7$ & $28.8 \pm 0.4$ \\
\hline \multicolumn{5}{|c|}{ Lactose $(\mathrm{g} / \mathrm{kg})$} \\
\hline Primiparous & $39.1 \pm 1.0$ & $39.4 \pm 1.0$ & $40.9 \pm 1.0$ & $39.8 \pm 0.6$ \\
\hline Multiparous & $40.4 \pm 0.7$ & $40.4 \pm 0.7$ & $39.7 \pm 0.7$ & $40.2 \pm 0.4$ \\
\hline Mean & $39.7 \pm 0.6$ & $39.9 \pm 0.6$ & $40.3 \pm 0.6$ & $40.0 \pm 0.4$ \\
\hline \multicolumn{5}{|c|}{ Total solids (g/kg) } \\
\hline Primiparous & $103.8 \pm 3.6$ & $103.7 \pm 3.6$ & $104.3 \pm 3.6$ & $103.9 \pm 2.1$ \\
\hline Multiparous & $105.2 \pm 2.8$ & $104.2 \pm 2.8$ & $101.1 \pm 2.8$ & $103.5 \pm 1.6$ \\
\hline Mean & $104.5 \pm 2.3$ & $103.9 \pm 2.3$ & $102.7 \pm 2.3$ & $103.7 \pm 1.3$ \\
\hline \multicolumn{5}{|c|}{ Acidity $\left({ }^{\circ} \mathrm{D}\right)$} \\
\hline Primiparous & $15.78 \pm 1.05$ & $14.32 \pm 1.05$ & $13.88 \pm 1.05$ & $14.67 \pm 0.61$ \\
\hline Multiparous & $15.54 \pm 0.81$ & $16.08 \pm 0.81$ & $14.83 \pm 0.81$ & $15.49 \pm 0.47$ \\
\hline Mean & $15.67 \pm 0.67$ & $15.20 \pm 0.67$ & $14.35 \pm 0.67$ & $15.08 \pm 0.38$ \\
\hline \multicolumn{5}{|c|}{ Somatic cell counts $\left(\log _{10}\right)$} \\
\hline Primiparous & $3.17 \pm 0.18$ & $3.60 \pm 0.18$ & $3.25 \pm 0.18$ & $3.34 \pm 0.10$ \\
\hline Multiparous & $3.18 \pm 0.14$ & $3.15 \pm 0.14$ & $2.88 \pm 0.14$ & $3.07 \pm 0.08$ \\
\hline Mean & $3.17 \pm 0.11$ & $3.37 \pm 0.11$ & $3.07 \pm 0.11$ & $3.20 \pm 0.06$ \\
\hline
\end{tabular}


Paape et al. (2007). However, clinical mastitis was not observed. For goats, non-infectious factors such as estrus, season, milk production, parity and days of lactation can influence the SCC in milk (Paape et al., 2007).

\section{Conclusions}

Inactive dry yeast can replace soybean meal in diets for lactating Saanen goats, once it does not alter the dry matter intake, milk yield and composition or feed efficiency during the different lactations phases.

\section{References}

AMORIM, H.V.; LOPES, M.L. Tecnologia sobre processamento de leveduras vivas, inativas e seus derivados: conceitos básicos. In: CONGRESSO SOBRE USO DE LEVEDURA NA ALIMENTAÇÃO ANIMAL, 1., 2009, Campinas. Anais... Campinas: Colégio Brasileiro de Nutrição Animal, 2009. p.5-19.

ARAÚJO, F.F.; SILVA, C.C. Leveduras hidrolisadas e inativas. In: CONGRESSO INTERNACIONAL SOBRE O USO DE LEVEDURA NAALIMENTAÇÃO ANIMAL, 1., 2009, Campinas. Anais... Campinas: Colégio Brasileiro de Nutrição Animal, 2009. p.37-44.

ASSOCIATION OF OFFICIALAGRICULTURALCHEMISTS - AOAC. Official methods of analysis. 16.ed. Gaithersburg: Association of Official Analytical Chemists, 1998. 1141p.

BRASIL. Ministério da Agricultura. Instrução Normativa $n^{\circ} 37$. Regulamento técnico de produção, identidade e qualidade do leite de cabra. Diário Oficial da União, Brasília, 8 nov. 2000. p.6.

KALA, S.N.; PRAKASH, B. Genetic and phenotypic parameters of milk yield and milk composition in two Indian goats breeds. Small Ruminant Research, v.3, p.475-484, 1990.

LIMA, L.S. Produção de leite de cabra e fermentação ruminal utilizando rações com levedura seca (Saccharomyces cerevisiae). 2010. 65f. Dissertação (Mestrado em Zootecnia) - Universidade Estadual de Maringá, Maringá.

MENDES, C.Q.; FERNANDES, R.H.R.; SUSIN, I. et al. Substituição parcial do farelo de soja por ureia ou amireia na alimentação de cabras em lactação. Revista Brasileira de Zootecnia, v.39, n.8, p.1818-1824, 2010.

MORAND-FEHR, P. Recent developments in goat nutrition and application: A review. Small Ruminant Research, v.60, p.25-43, 2005.

NATIONAL RESEARCH COUNCIL - NRC. Nutrient requirements of small rumiants, Washington, D.C.: National Academy Press, 2007. 362p.

PAAPE, M.J.; WIGGANS, G.R.; BANNERMAN, D.D. et al. Monitoring goat and sheep milk somatic cel counts. Small Ruminant Research, v.68, p.114-125, 2007.

PINA, D.S.; VALADARES FILHO, S.C.; VALADARES, R.F.D. et al. Consumo e digestibilidade aparente total dos nutrientes, produção e composição do leite de vacas alimentadas com dietas contendo diferentes fontes de proteína. Revista Brasileira de Zootecnia, v.35, n.4, p.1543-1551, 2006.

PULINA, G.; NUDDA, A.; BATTACONE, G. et al. Nutrition and quality of goat's Milk. In: CANNAS, A.; PULINA, G. (Eds.) Dairy goats feeding and nutrition. 2.ed. Bologna, 2008. p.1-30.

QUEIROGA, R.C.R.E.; COSTA, R.G. Qualidade do leite caprino. In: SIMPÓSIO INTERNACIONAL DE CONSERVAÇÃO DE RECURSOS GENÉTICOS. RAÇAS NATIVAS PARA O SEMIÁRIDO, 1., 2004. Recife. Anais... Recife: Universidade Federal Rural de Pernambuco, 2004. p.161-171.

QUEIROGA, R.C.R.E.; COSTA, R.G.; BISCONTINI, T.M.B. et al. Influência do manejo do rebanho, das condições higiênicas da ordenha e da fase de lactação na composição química do leite de cabras Saanen. Revista Brasileira de Zootecnia, v.36, n.2, p.430-437, 2007.

RODRIGUES, L.; SPINA, J.R.; TEIXEIRA, I.A.M.A. et al. Produção, composição do leite e exigências nutricionais de cabras Saanen em diferentes ordens de lactação. Acta Scientiarum. Animal Sciences, v.28, n.4, p.447-452, 2006.

RODRIGUES, C.A.F.; RODRIGUES, M.T.; BRANCO, R.H. et al. Consumo, digestibilidade e produção de leite de cabras leiteiras alimentadas com dietas contendo diferentes níveis de proteína bruta e energia líquida. Revista Brasileira de Zootecnia, v.36, n.5, p.1658-1665, 2007 (supl.)

SANTOS, M.V.; FONSECA, L.F.L. Modificação do teor e da composição da proteína do leite. In: Estratégias para controle de mastite e melhoria da qualidade do leite. Barueri: São Paulo, 2007. p.220-230.

SNIFFEN, C.J.; O'CONNOR, J.D.; VAN SOEST, P.J. et al. A net carbohydrate and protein system for evaluating cattle diets: II. Carbohydrate and protein availability. Journal of Animal Science, v.70, n.10, p.3562-3577, 1992.

VAN SOEST, P.J. Methods for dietary fiber, neutral detergent fiber, and nonstarch polysaccharides in relation to nutrition. In: Symposium Carbohydrate Methodology, Metabolism, and Nutritional Implications in Dairy Cattle. Journal of Dairy Science, v.74, n.10, p.3583-3597, 1991.

VILANOVA, M; GONÇALVES, M; OSÓRIO, M.T. et al. Aspectos sanitários do úbere e composição química do leite de cabras Saanen. Acta Scientiae Veterinariae, v.36, n.3, p.235-240, 2008.

VOLTOLINI, T.V.; SANTOS, G.T.; ZAMBOM, M.A. et al. Influência dos estádios de lactação sobre a contagem de células somáticas do leite de vaca da raça Holandesa e identificação de patógenos causadores de mastite no rebanho. Acta Scientiarum.Animal Science, v.23, p.961-966, 2001.

ZAMBOM, M.A. Desempenho produtivo, digestibilidade e características ruminais de cabras Saanen recebendo rações com casca do grão de soja em substituição ao milho. 2006. 148f. Tese (Doutorado em Zootecnia) - Universidade Estadual de Maringá, Maringá.

ZAMBOM, M.A.; ALCALDE, C.R.; SILVA, K.T. et al. Ingestão, digestibilidade das rações e produção de leite em cabras Saanen submetidas a diferentes relações volumoso:concentrado na ração. Revista Brasileira de Zootecnia, v.34, n.6, p.2505-2514, 2005 (supl.). 